\title{
Effects of Sodium Hydroxide Treatment and Soybean Meal Supplementation on Digestion and Utilization of Rice Straw by Sheep
}

\author{
Jian Xin LiU, Masahiko Okubo and Yasushi Asamida \\ Faculty of Agriculture, Hokkaido University, Sapporo-shi 060
}

(Received March 28, 1988)

\begin{abstract}
Using three wethers, we studied the effects of $\mathrm{NaOH}$ treatment and soybean meal (SBM) supplementation on nutrient digestibility, nitrogen (N) balance and energy utilization of rice straw. The untreated rice straw (RS) was either given alone or supplemented with 100,200 or 300 g SBM per day, and $\mathrm{NaOH}$-treated rice straw (ARS) was either given alone or supplemented with 200 g SBM per day. The SBM supplementation significantly increased the digestibility of RS diet nutrients $(P<0.05)$. There was, however, little difference in nutrient digestibility among the SBM-supplemented RS diets. Alkali treatment significantly increased the digestibility of nutrients of $\mathrm{RS}(\mathrm{P}<0.05)$, but SBM supplementation had no further effect on the nutrient digestibility of ARS. The intake, digestibility and retention of $\mathrm{N}$ increased with the increasing level of SBM supplemetation $(P<0.05)$, but increased $N$ intake was also associated with an increase in urinary $\mathrm{N}$ loss. Alkali treatment increased $\mathrm{N}$ digestibility and decreased urinary $\mathrm{N}$ loss $(\mathrm{P}<0.05)$. The supplementation of ARS with SBM further increased $\mathrm{N}$ digestibility $(\mathrm{P}<0.05)$ and hence $\mathrm{N}$ retention. The intake, digestibility and metabolizability of energy significantly increased due to SBM supplementation and alkali treatment $(P<0.05)$. The metabolizable energy content was the highest in the SBM-supplemented ARS diet.
\end{abstract}

Jpn. J. Zootech. Sci., 60 (1) : 40-45, 1989

Key words : rice straw, $\mathrm{NaOH}$ treatment, soybean meal, utilization, sheep

In previous experiments ${ }^{1,2)}$, we studied the effects of $\mathrm{NaOH}$ treatment and soybean meal (SBM) supplementation on the voluntary intake of rice straw. The voluntary intake of rice straw did not increase greatly by SBM supplementation or $\mathrm{NaOH}$ treatment, while the combination of alkali treatment and SBM supplementation greatly increased the voluntary intake of rice straw through the improvement of fibrous material digestion in the rumen ${ }^{1,2)}$.

The present experiment was conducted to study the effects of $\mathrm{NaOH}$ treatment and SBM supplementation on the digestion and utilization of rice straw by wethers.

\section{Materials and Methods}

Three Suffolk cross wethers weighing about $80 \mathrm{~kg}$ were used. Their managements were the same as described previously ${ }^{3)}$. 
The untreated rice straw (RS) was the same as that used in the previous study ${ }^{1)}$ and the $\mathrm{NaOH}$-treated rice straw (ARS) was prepared with the same method as described previously ${ }^{2}$.

The experimental designs were also similar to those reported previously ${ }^{1,2)}$. The RS was offered alone ad libitum (Control) or supplemented with SBM at 100, 200 or $300 \mathrm{~g}$ per day. The ARS was offered to wethers alone or supplemented with $200 \mathrm{~g}$ SBM per day.

Nutrient digestibility, nitrogen balance and energy utilization were determined for every treatment. Details of digestion and metabolism trials are the same as described elsewhere ${ }^{3)}$.

The results were analyzed as a $2 \times 2$ factorial design using the methods of STEEL and TORRIE ${ }^{4}$. When SBM supplementation effect was significant, four levels of SBM supplementation within RS were compared using DUNCAN's new multiple range test ${ }^{4}$.

\section{Results and discussion}

Table 1 shows the nutrient digestibility of RS and ARS offered alone or supplemented with SBM.

The digestibility of dry matter (DM), organic matter (OM), cell wall constituents (CWC) and acid detergent fiber (ADF) of RS significantly increased as a result of $100 \mathrm{~g}$ SBM supplementation. There was, however, no further increase in digestibility due to 200 or $300 \mathrm{~g}$ SBM supplementation. The digestibility of crude protein (CP) increased with the increasing level of SBM supplementation, though little increase in $\mathrm{CP}$ digestibility was obtained by SBM supplementation above $200 \mathrm{~g}$.

When the OM digestibility of SBM was assumed to be $79 \%$, the OM digestibilities of RS were estimated to be $50.8,52.5$ and $54.0 \%$ for 100,200 and 300 g SBM-

Table 1. Dry matter (DM) intake and digestibility of nutrients of untreated (RS) and alkali-treated rice straw (ARS) offered alone or supplemented with soybean meal (SBM)

\begin{tabular}{|c|c|c|c|c|c|c|}
\hline \multirow{2}{*}{$\begin{array}{l}\text { Straw } \\
+ \text { SBM, g/d }\end{array}$} & \multicolumn{4}{|c|}{$\mathrm{RS}$} & \multicolumn{2}{|c|}{ ARS } \\
\hline & 0 & 100 & 200 & 300 & 0 & 200 \\
\hline \multicolumn{7}{|c|}{ DM intake, $\mathrm{g} / \mathrm{d}$} \\
\hline Straw & $938^{A}$ & 1136 & $1197^{\mathrm{A}}$ & 1225 & $1284^{\mathrm{aB}}$ & $1735^{\mathrm{bB}}$ \\
\hline Total & $938^{\mathrm{aA}}$ & $1223^{b}$ & $1348^{\mathrm{bA}}$ & $1456^{b}$ & $1284^{\mathrm{aB}}$ & $1912^{6 \mathrm{~B}}$ \\
\hline \multicolumn{7}{|c|}{ Digestibility,\% } \\
\hline $\mathrm{DM}$ & $41.6^{\mathrm{aA}}$ & $52.1^{b}$ & $55.3^{b}$ & $54.6^{b}$ & $61.1^{8}$ & 60.5 \\
\hline $\mathrm{OM}$ & $48.6^{\text {at }}$ & $57.1^{b}$ & $58.6^{\mathrm{b}}$ & $59.1^{b}$ & $65.6^{\mathrm{B}}$ & 64.8 \\
\hline $\mathrm{CP}$ & $20.4^{\mathrm{aA}}$ & $57.5^{b}$ & $70.5^{\mathrm{CA}}$ & $71.1^{c}$ & $34.6^{\mathrm{aB}}$ & $59.9^{\mathrm{bE}}$ \\
\hline $\mathrm{CWC}$ & $43.3^{\mathrm{aA}}$ & $50.8^{b}$ & $50.4^{\mathrm{ba}}$ & $48.2^{\mathrm{ab}}$ & $65.3^{\mathrm{B}}$ & $62.6^{\mathrm{B}}$ \\
\hline $\mathrm{ADF}$ & $33.0^{a A}$ & $42.8^{b}$ & $46.9^{\mathrm{bA}}$ & $41.7^{b}$ & $57.4^{8}$ & $53.6^{8}$ \\
\hline
\end{tabular}

a, b. c: Means with different superscripts within same straw differ $(P<0.05)$, indicating the effect of SBM supplementation.

A, B : Means with different superscripts within same supplementation treatment differ $(P<0.05)$, indicating the effect of alkali treatment. 


\section{Liu, Okubo and Asahida}

supplemented RS diets, respectively. These estimated values were slightly lower than the measured values (Table 1), and this suggests that SBM supplementation only slightly increased straw digestiblity.

Alkali treatment significantly increased the nutrient digestibility of RS $(\mathrm{P}<0.05)$. The SBM supplementation to ARS had little eff ect on nutrient digestibility except for $\mathrm{CP}$, the digestibility of which was further increased by SBM supplementation $(\mathrm{P}<$ 0.05). Similar results have been observed by Moran et al. ${ }^{6}$, who offered either untreated or $\mathrm{NaOH}$-treated rice straw to buffalo either alone or supplemented with Leucaena (a legume tree).

It has been demonstrated that alkali structurally change the epidermis and vascular bundle sheath of $\mathrm{RS}^{7,8)}$. We also observed that alkali treatment greatly increased the potential extent of CWC digestion of the $\mathrm{RS}^{2)}$. This could account for the improved digestibility of the RS diet. When ARS was supplemented with a $N$ source, the rate of ruminal passage of the digesta increased ${ }^{2,9)}$ and this may have resulted in no further increase in nutrient digestibility.

The results of $\mathrm{N}$ balance are shown in Table 2. Supplementation of SBM increased $\mathrm{N}$ intake, urinary $\mathrm{N}$ loss and $\mathrm{N}$ retention. Expressed as a percentage of $\mathrm{N}$ intake, the proportion of urinary $\mathrm{N}$ to $\mathrm{N}$ intake increased with the increasing level of SBM supplementation, suggesting that the $\mathrm{N}$ ingested from supplementary SBM was ineff ectively utilized.

Due to the increased straw intake by alkali treatment, $\mathrm{N}$ intake was higher in sheep fed ARS than those fed RS. Alkali treatment decreased the proportion of $\mathrm{N}$ loss in feces and urine to $\mathrm{N}$ intake. However $\mathrm{N}$ retention was close to zero in animals fed ARS. Supplementation of ARS with SBM decreased the proportion of fecal $\mathrm{N}$ loss

Table 2. Nitrogen balance by sheep fed untreated (RS) or alkali-treated rice straw (ARS) alone or supplemented with soybean meal (SBM)

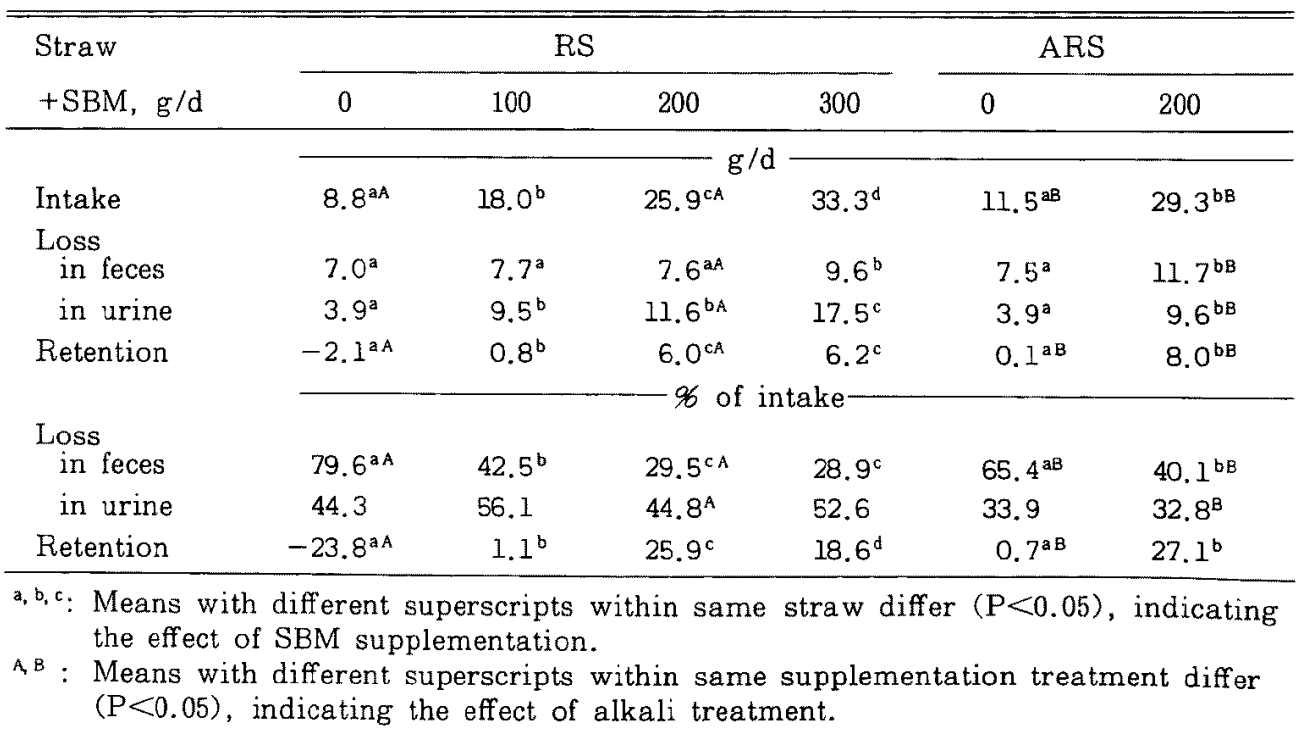


and did not increase the percentage of urinary $\mathrm{N}$ loss. The proportion of $\mathrm{N}$ retention to $\mathrm{N}$ intake was $27.1 \%$ in animals fed ARS with SBM supplementation.

The results of energy utilization are given in Table 3. Digestibility and metabolizability of energy derived from RS were significantly improved by $100 \mathrm{~g}$ SBM supplementation $(P<0.05)$, then leveled off. The intake of digestible $(D E)$ and metabolizable energy (ME) also increased with $100 \mathrm{~g}$ SBM supplementation $(\mathrm{P}<0.05)$.

Alkali treatment significantly increased the energy digestibility of $\mathrm{RS}(\mathrm{P}<0.05)$ and decreased the proportion of urinary energy loss to GE intake, which may be associated with decreased urinary $\mathrm{N}$ excretion (Table 2). Energy metabolizability was increased 17 percentage units with alkali treatment. Both digestibility and metabolizability of energy were improved more by alkali treatment than by SBM supplementation. Supplementation of ARS with SBM further improved digestibility and metabolizability $(\mathrm{P}<0.05)$.

Table 4 shows the nutritive value of RS diets and the ratio of ME intake to the energy requirement for maintenance $(\mathrm{MEm})^{11}$. In connection with the improved digestibility and metabolizability of energy, the contents of DE and ME were enhanced by $100 \mathrm{~g}$ SBM supplementation $(\mathrm{P}<0.05)$, then leveled off. The ME content of ARS was equivalent to that of 200 or $300 \mathrm{~g}$ of SBM-supplemented RS diet. The SBM supplementation to ARS further increased the ME content. The digestible CP content increased with the increasing level of SBM supplementation.

Table 3. Energy utilization by sheep fed untreated (RS) or alkali-treated rice straw (ARS) alone or supplemented with soybean meal (SBM)

\begin{tabular}{|c|c|c|c|c|c|c|}
\hline \multirow{2}{*}{$\begin{array}{l}\text { Straw } \\
+ \text { SBM, g/d }\end{array}$} & \multicolumn{4}{|c|}{$\mathrm{RS}$} & \multicolumn{2}{|c|}{ ARS } \\
\hline & 0 & 100 & 200 & 300 & 0 & 200 \\
\hline & & & $-\mathrm{kJ} / \mathrm{kg}$ & 5 & & \\
\hline$\underset{G E}{\text { Intake }}$ & $557^{\text {aA }}$ & $706^{b}$ & $796^{\mathrm{bA}}$ & $866^{b}$ & $793^{\mathrm{aB}}$ & $1329^{\mathrm{bB}}$ \\
\hline $\mathrm{DE}$ & $243^{\text {aA }}$ & $379^{b}$ & $451^{\mathrm{bA}}$ & $490^{b}$ & $478^{\mathrm{aB}}$ & $914^{\mathrm{bB}}$ \\
\hline $\mathrm{ME}$ & $187^{\text {aA }}$ & $299^{\circ}$ & $358^{\mathrm{DA}}$ & $386^{\circ}$ & $399^{\text {ав }}$ & $812^{\mathrm{bB}}$ \\
\hline \multicolumn{7}{|l|}{ Loss in } \\
\hline Methane ${ }^{1 \prime}$ & 37 & 51 & 58 & 63 & 60 & 64 \\
\hline \multicolumn{7}{|l|}{ Intake } \\
\hline $\mathrm{DE}$ & $43.3^{\mathrm{aA}}$ & $53.5^{\mathrm{b}}$ & $56.7^{\mathrm{bA}}$ & $56.5^{b}$ & $60.2^{\mathrm{aB}}$ & $65.0^{\mathrm{bB}}$ \\
\hline $\mathrm{ME}$ & $33.3^{\mathrm{aA}}$ & $46.3^{b}$ & $45.0^{\mathrm{bA}}$ & $44.8^{b}$ & $50.2^{\mathrm{aB}}$ & $57.3^{\mathrm{bB}}$ \\
\hline $\begin{array}{l}\text { Loss in } \\
\text { Urine }\end{array}$ & 3.4 & 4.1 & 4.4 & 4.7 & 2.4 & 2.9 \\
\hline Methane & 6.6 & 7.2 & 7.3 & 7.0 & 7.6 & 4.8 \\
\hline
\end{tabular}

1) Methane production was calculated with the equation presented by BLAXTER and Clapperton ${ }^{10}$ ?

$a, b$ : Means with different superscripts within same straw differ $(P<0.05)$, indicating the effect of SBM supplementation.

$A, B$ : Means with different superscripts within same supplementation treatment differ $(P<0.05)$, indicating the effect of alkali treatment. 


\section{Liv, OKubo and Asahida}

Table 4. Nutritive value of untreated (RS) and alkali-treated rice straw (ARS) offered alone or supplemented with soybean meal (SBM)

\begin{tabular}{|c|c|c|c|c|c|c|}
\hline \multirow{2}{*}{$\begin{array}{l}\text { Straw } \\
+ \text { SBM, g/d } \\
\end{array}$} & \multicolumn{4}{|c|}{$\mathrm{RS}$} & \multicolumn{2}{|c|}{ ARS } \\
\hline & 0 & 100 & 200 & 300 & 0 & 200 \\
\hline \multicolumn{7}{|c|}{ Energy value, $\mathrm{MJ} / \mathrm{kg} \mathrm{DM}$} \\
\hline $\mathrm{GE}$ & 16.1 & 16.4 & 16.6 & 16.7 & 15.6 & 16.0 \\
\hline DE & 7.0 & 8.8 & 9.4 & 9.4 & 9.4 & 10.4 \\
\hline $\mathrm{ME}$ & 5.3 & 7.6 & 7.5 & 7.5 & 7.8 & 9.2 \\
\hline DCP, $\not 6 ~ D M$ & 1.1 & 5.3 & 8.3 & 10.0 & 2.0 & 6.0 \\
\hline $\mathrm{MEI} / \mathrm{MEm}^{11}$ & 0.50 & 0.72 & 0.86 & 1.01 & 1.05 & 1.93 \\
\hline
\end{tabular}

1) Ratio of metabolizable energy intake. (MEI) to $\mathrm{ME}$ requirement for maintenance (MEm)

The ratios of $\mathrm{ME}$ intake to $\mathrm{MEm}$ were $0.50,0.72,0.86$ and 1.01 for the Control, 100,200 and $300 \mathrm{~g}$ SBM-supplemented RS diets, respectively. The RS, when given either alone or supplemented with 100 or $200 \mathrm{~g}$ SBM, would not satisfy the ME requirement for maintenance. The $\mathrm{ME}$ intake of sheep offered $\mathrm{RS}$ supplemented with $300 \mathrm{~g}$ SBM was equal to that of animals fed ARS alone. When the ARS was supplemented with SBM, the ME intake was increased to about twice the MEm.

From these results and the voluntary intake of rice straw ${ }^{1,2)}$, it is suggested that SBM supplementation does not greatly affect the intake, digestibility and utilization of rice straw, and that the beneficial effect of alkali treatment arises mainly from an improvement in the digestibility of nutrients. Meanwhile, SBM supplementation will increase ARS intake to a great extent.

\section{References}

1) Liu, J.X., M. Okubo and Y. Asahida, Jpn. J. Zootech. Sci., $59: 1034-1039.1988$.

2) Lru, J.X., M. Oкuво and Y. AsahidA, Jpn. J. Zootech. Sci., 59 : 1040-1046. 1988.

3) Liu, J.X., S. Kondo, J. Sekine, M. Okubo and Y. Asahida, J. Fac. Agr. Hokkaido Univ., 63 : 125-135. 1986.

4) Steel, R.G.D. and J.H. Torrie, Principles and Procedures of Statistics. 194-231. 305-331. McGraw-Hill Book Co. New York. 1960.

5) Ministry of Agriculture, Fisheries and Food, Energy Allowances and Feeding Systems for Ruminants. Tech. Bull. No. 33. Her Majesty's Stationery Office. London. 1975.

6) Moran, J.B., K.B. Satoto and J.E. Dawson, Aust. J. Agric. Res., 34 : 73-84. 1983.

7) Shinoda, M., S. Hori and A. Abe, Bull. Nat. Inst. Anim. Ind., 42:21-27. 1984. (in Japanese)

8) Yamatani, Y., K. Taniguchi and I. Otani, J. Fac. Appl. Bio. Sci. Hiroshima Univ., $19:$ 265-273. 1980. (in Japanese)

9) Coombe, J.B., D.A. Dinius and W.E. Wheeler, J. Anim. Sci., 49: 169-176. 1979.

10) Blaxter, K.L. and J.L. Clapperton, Br. J. Nutr., 19:511-522. 1965.

11) Agricultural Research Council, The Nutrient Requirements of Ruminant Livestock. 73-119. Commonwealth Agricultural Bureaux. Slough. 1980. 


\section{$\mathrm{NaOH}$ 処理と大豆粕添加が稲わらの養分消化率, 窒素・エネルギー利用に及ぼす影響 \\ 劉 建新・大久保正彦・朝日田康司} 北海道大学農学部, 札幌市 060

3頭のめん羊を供試し， $\mathrm{NaOH}$ 処理と大豆粕添加加 稲わらの養分消化率, 窒素出納およびエネルギー利用に 及ぼす影響について検討した，稲わら（RS）に同重量 の $\mathrm{NaOH}$ 水溶液 $(40 \mathrm{~g} \mathrm{NaOH} / \mathrm{kg}$ 水) を撒布して $\mathrm{NaOH}$ 処理わら (ARS) を調製した. 大豆粕添加量は, RSにはそれぞれ，0，100，200，300g とし，ARSに はそれぞれ，0，200 g とした，RSの各成分消化率と あ無添加に比へ $100 \mathrm{~g}$ 大豆粕添加時に有意に向上した $(\mathrm{P}<0.05)$ が各添加区間に差がなかった. $\mathrm{NaOH}$ 処理 は各成分の消化率を大幅に增加させた $(\mathrm{P}<0.05)$ が, 更に大豆粕を添加しても各成分の消化率とも殆ど变化し
なかった。窒素摂取量, 消化率および蓄積とも大豆粕 添加により増加したが，尿中窒素損失割合も高くなり， 大豆粕添加により増加した窒素摂取量は必ずしも効率よ く利用されなかった。 $\mathrm{NaOH}$ 処理により糞中，尿中空 素の割合とも減少し，ARS に大豆粕を添加すると窒素 消化率，蓄積成績とも改善された。エネルギーの摂取量， 消化率および代鲋率とも，大豆粕および $\mathrm{NaOH}$ 処理の いずれによってい改善された $(\mathrm{P}<0.05)$. 代謝エネル ギー含量は ARSに大豆粕を添加した場合に最も高か った.

日畜会報 $60(1) ： 40-45 ， 1989$ 